\title{
СТОМАТОЛОГІя
}

(C) Є.Ю. Локота, С.І. Оплета, Ю.Є. Локота, 2019

УДК: 616.314-089.23-053.67(477.87):005.584.1

\section{Моніторинг ортопедичних конструкцій для лікування осіб молодого віку м. Ужгород із наявністю малих включених дефектів зубних рядів}

\author{
Є.Ю. Локота, С.І. Оплета, Ю.С. Локота \\ sofiaopleta@gmail.com \\ Ужгородський національний університет, стоматологічний факультет, кафедра \\ ортопедичної стоматологї, Ужгород
}

\section{Реферат}

Вступ. Серед питань сучасної ортопедичної стоматології набирає актуальності проблема наявності малих дефектів зубних рядів в осіб молодого віку. Такі пацієнти рідко звертаються за стоматологічною допомогою. Дані дефекти не викликають значного порушення жувальної функції, однак протягом часу це спричинює не лише порушення морфологічної єдності зубних рядів, але й деформацію прикусу та складну органічну перебудову в ділянці дефекту, що згодом може поширитися на весь зубний ряд. Отже, вивчення особливостей протезування таких пацієнтів сприятиме покращенню заходів лікування, спрямованих на усунення дефектів, що передбачає зниження рівня захворюваності населення.

Мета дослідження: комплексно обстежити ортопедичні захворювання в осіб молодого віку міста Ужгород; підвищити ефективність протезування хворих із малими дефектами зубних рядів для профілактики вторинних дентоальвеолярних деформацій; обгрунтувати вибір оптимального виду ортопедичної допомоги для результативного лікування.

Матеріали та методи. Проведено стоматологічні огляди 975 пацієнтів віком 15-29 років на базі Університетської стоматологічної поліклініки міста Ужгород. Об'єктом дослідження були малі включені дефекти бічних ділянок зубних рядів та їх ускладнення у осіб молодого віку.

Результати досліджень та їх обговорення. За допомогою комплексних досліджень отримані дані щодо поширення малих дефектів зубних рядів серед молодих осіб віком 15-29 років міста Ужгород; проаналізовано динаміку захворюваності в цілому. Практичне значення одержаних результатів полягає у наданні об'єктивної стоматологічної допомоги пацієнтам даної вікової категорії, що включає в себе розробку ефективних методів ортопедичного лікування та профілактики зубощелепних деформацій.

Висновки. На підставі дослідження поширеності, інтенсивності, тенденції розвитку малих включених дефектів зубних рядів серед осіб молодого віку м. Ужгород, проаналізовано динаміку захворюваності в цілому, визначено спрямованість і силу впливу негативних патогенетичних чинників на перебіг і формування різноманітних порушень із боку зубощелепної системи.

Ключові слова: стоматологічний огляд, особи молодого віку, малі включені дефекти зубного ряду, ортопедична захворюваність, ортопедична конструкція.

Monitoring of prosthetic constructions structures for treatment of young people of Uzhhorod with the small included defects of the dentitions dental

Ye.Yu. Lokota, S.I. Opleta, Yu.Ye Lokota

Uzhhorod National University, Faculty of Dentistry, Department of Prosthetic Dentistry, Uzhhorod

Abstract
Introduction. Among the issues of modern orthopedic dentistry, the problem of the presence of small defects in the dentition in young people is becoming more urgent. Such patients rarely seek for dental care. These defects do not cause significant impairment of masticatory function, but over the time, this causes not only the violation of the morphological unity of dentitions, but also deformation of the bite and complex organic adjustment in the defect area, which may subsequently extend to all dentition. Therefore, the study of the features of prosthetics of such patients will improve the treatment of defects, which reduces the incidence of the population.

Aim of research. Comprehensive to examinate of orthopedic diseases of young people of Uzhhorod; to increase the efficiency of prosthetics of patients with small defects of dentitions for the prevention of secondary dentoalveolar deformities; to justify the choice of the optimal type of prosthetic care for effective treatment.

Materials and methods. Dental examinations of 975 patients aged 15-29 years were conducted on the basis of the Uzhgorod University Dental Clinic. The object of the study was small included defects in the lateral areas of the dentition and their complications in young adults. 
Results and discussion. Through comprehensive research data were obtained on the spread of small defects in the dentition among young people aged 15-29 years in Uzhhorod; the dynamics of morbidity as a whole is analyzed The practical value of the results consists in rendering objective dental care to patients of this age category, which includes the development of effective methods of prosthetic treatment.

Conclusion. On the basis of the study of prevalence, intensity, tendency of development of small included defects of dentitions among young people of Uzhhorod, the dynamics of morbidity as a whole is analyzed, the direction and power of influence of negative pathogenetic factors on the course and formation of various abnormalities by the system are determined.

Key words: dental exploring, young persons, small included dentition defects, prosthetic morbidity, prosthetic construction.

Вступ. Останнім часом в Україні все більше приділяється увага питанням стоматологічної ортопедичної захворюваності серед осіб молодого віку [1]. Серед питань сучасної ортопедичної стоматології також набирає актуальності проблема наявності малих дефектів зубних рядів в осіб молодого віку [2]. За даними вітчизняних та закордонних епідеміологічних досліджень високий рівень поширеності такої патології в бічних відділах саме у молодих осіб може бути зумовлений раннім видаленням, найчастіше перших молярів. Їх рання втрата пов'язана із несвоєчасним лікуванням, ушкодженнями каріозного та некаріозного походження [3]. Пацієнти 3 невеликими дентоальвеолярними деформаціями, особливо в молодому віці, рідко звертаються за стоматологічною допомогою. Такі деформації не викликають значного порушення жувальної функції, однак протягом часу це спричинює не лише порушення морфологічної єдності зубних рядів, але й деформацію прикусу та складну органічну перебудову в ділянці дефекту, що згодом може поширитись на весь зубний ряд. Це, у свою чергу, сприяє функціональному перевантаженню тканин пародонта зубів, що обмежують дефект, i відсутності відповідного функціонального навантаження на пародонт зубів-антагоністів; порушенню функції жувальних м'язів і провокує розлади скроневонижньощелепного суглоба $[4,5,6]$. У період молодого віку будь-які зміни в зубощелепній системі призводять до виникнення і швидких темпів прогресування оклюзійних деформацій. Отже, можна передбачити, що несвоєчасність втручань, спрямованих на відновлення малих дефектів зубних рядів, спонукає до породження цілого комплексу вельми тяжких і складних клінічних ускладнень, що утруднює ортопедичне лікування $[7,5]$. Важливе соціальне і медичне значення представляють питання розвитку даної патології в часовому діапазоні, як у віковому аспекті, так і динаміка іiі розвитку в часі [8]. Встановлено кореляційну залежність виникнення деформацій. Частота зубощелепних аномалій має прямий кореляційний зв'язок зі ступенем деформації зубощелепної системи, яка зростає зі збільшенням часу наявності дефекту зубного ряду $[3,9]$. Тому проблема часткових включених дефектів малої протяжності залишається актуальною в теперішній час, що, зі свого боку, визначає необхідність невідкладного відновлення цілісності зубного ряду за допомогою використання різноманітних ортопедичних конструкцій. Отже, вивчення особливостей протезування таких пацієнтів сприятиме покращенню заходів лікування, спрямованих на усунення дефектів, що, у свою чергу, передбачає зниження рівня захворюваності населення.

Мета дослідження. Визначення загального комплексного стану стоматологічної ортопедичної захворюваності у осіб молодого віку міста Ужгород. Підвищення ефективності протезування хворих із малими дефектами зубних рядів для профілактики вторинних дентоальвеолярних деформацій. Обгрунтування вибору оптимального виду ортопедичної допомоги для результативного лікування.

Матеріали та методи. Проведено стоматологічні огляди 2830 пацієнтів віком 15-29 років на базі Університетської стоматологічної поліклініки міста Ужгород. Об'єктом дослідження були малі включені дефекти бічних ділянок зубних рядів та їх ускладнення у осіб молодого віку. На діагностичних моделях проведені аналіз та визначення параметрів дефектів зубних рядів. Проаналізовано дані раніше проведених досліджень О.В. Лабунець осіб 15-29 років в Одесі, Тернополі та Івано-Франківську. Визначення вікових груп проводилося згідно 3 методичними рекомендаціями Комітету експертів ВО3 (1980р.). Основною характеристикою статистичної обробки було обчислення середньоарифметичних величин.

Результати досліджень та їх обговорення. У ході дослідження протягом 2019 року на базі Університетської стоматологічної поліклініки було оглянуто 975 осіб віком 15-29 років. В 419 пацієнтів, що складає 43\% обстежених, було виявлено малі включені дефекти бічних відділів зубних рядів. Їх було поділено на три вікових групи: 15-19 років - 54 особи; 20-24 роки - 101 особа; 25-29 років - 264 особи. У відсотковому співвідношенні ці значення становили відповідно: 13\%, 24\% і 63\% (рис. 1). 


\section{Вікові гру}

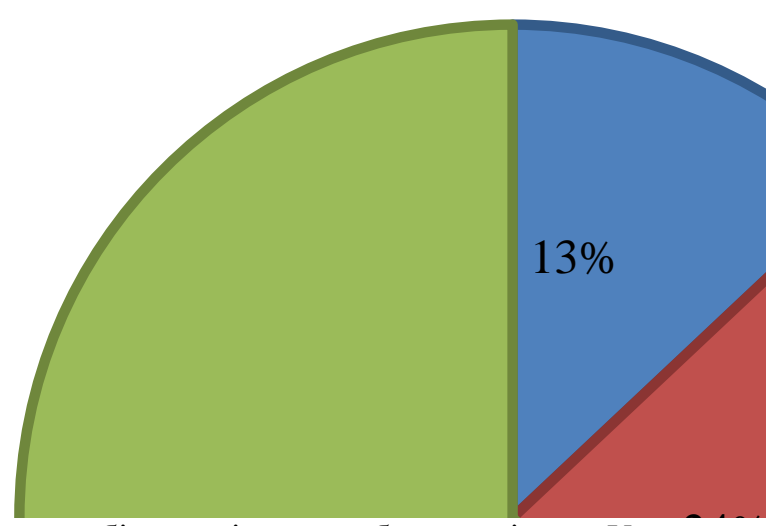

Рис. 1. Кількість осіб із малими включеними дефектами бічних ділянок зубних рядів у м.Ужгород.

Аналізуючи проведені обстеження, відзначимо помітне зростання показника осіб з дефектами зубних рядів із віком, що свідчить про їх пряму залежність. Це, у свою чергу, говорить про те, що чим більший вік пацієнта, тим більшою стає необхідність ортопедичної допомоги.

Схожі результати спостерігаємо й у дослідженнях, проведених О.В. Лабунець у найбільш характерних медико-географічних регіонах України зі стоматологічної захворюва- ності, а саме - у Одесі, Тернополі та ІваноФранківську в 2012 році. Відповідно до значень 3 таблиці 1 про ортопедичну захворюваність у цих містах та отриманих показників серед молодого населення м. Ужгород, можемо говорити про регіонарну залежність виникнення даної патології. Характерним для Одеси, Тернополя й Івано-Франківська залишається вікова залежність.

Частота виникнення та динаміка розвитку малих включених дефектів зубних рядів у осіб молодого віку на 1000 обстежених

\begin{tabular}{|l|c|c|c|c|c|c|}
\hline \multicolumn{7}{|c|}{ Вікові групи } \\
\hline \multirow{2}{*}{ Місто } & \multicolumn{2}{|c|}{$15-19$} & \multicolumn{2}{c|}{$20-24$} & \multicolumn{2}{c|}{$25-29$} \\
\hline Одеса & 250,0 & 25,0 & 358,7 & 35,9 & 618,2 & 61,8 \\
\hline $\begin{array}{l}\text { Тернопіль і Іва- } \\
\text { но-Франківськ }\end{array}$ & 404,3 & 40,4 & 579,5 & 58,0 & 842,1 & 84,2 \\
\hline
\end{tabular}

Згідно 3 отриманими даними гендерного розподілу, більшу частину пацієнтів із наявними дефектами зубних рядів становили чоловіки. Проте статистично значущої різниці між кількістю осіб чоловічої та жіночої статі не виявлено: 189 жінок (45\%) та 230 чоловіків (55\%). Згідно 3 наведеними в таблиці 2 даними, поділ за статтю відповідно до вікових груп відбувся таким чином: $15-19$ років -24 особи жіночої статі і 30 осіб чоловічої статі; $20-24$ роки - 45 осіб жіночої статі і 56 осіб чоловічої статі; 25-29 років - 119 осіб жіночої статі і 145 осіб чоловічої статі.

Таблиця 2

Характеристика гендерного розподілу пацієнтів

\begin{tabular}{|l|c|c|c|c|c|c|}
\hline \multicolumn{7}{|c|}{ Вікові групи } \\
\hline \multirow{2}{*}{ Стать } & \multicolumn{2}{|c|}{$15-19$} & \multicolumn{2}{c|}{$20-24$} & \multicolumn{2}{c|}{$25-29$} \\
\cline { 2 - 7 } & К-сть & $\%$ & к-сть & $\%$ & к-сть & $\%$ \\
\hline Жіноча & 24 & 5,7 & 45 & 10,7 & 119 & 28,4 \\
\hline Чоловіча & 30 & 7,2 & 56 & 13,3 & 145 & 34,6 \\
\hline
\end{tabular}


Беручи до уваги всі дані, слід звернути увагу на велику кількість пацієнтів молодого віку, що терміново потребують ортопедичну допомогу. Тому актуальним залишається питання заміщення малих включених дефектів. Раніше така проблема вирішувалася за допомогою встановлення класичних мостоподібних протезів. Але такий метод лікування передбачав зішліфовування близько 40-70\% твердих тканин опорних зубів, які часто депульповувалися. Проте сучасна стоматологія пропонує сьогодні безліч альтернативних варіантів, що допоможуть замістити відсутні зуби. Під час проведеного нами дослідження використовувалися такі методи лікування: імплантація, частковий знімний пластинчастий протез, адгезивні мостоподібні протези на волоконних і цільнолитих основах. Усе залежало від вигляду дефекту, його форми, величини, розміру та ступеня прояву, що ми визначали за допомогою діагностичних моделей. У процесі лікування усунення дефекту відбулося таким чином: 54 пацієнтам було встановлено імплантати, 67 пацієнтам зафіксовано мостоподібні кон- струкції, 113 пацієнтів отримали часткові знімні пластинчасті протези, 86 пацієнтам виготовлено адгезивні мостоподібні протези на волоконних основах та 99 - на цільнолитих основах.

Це свідчить про індивідуальність вибору підходящого виду протезування, що допоможе реконструювати зубний ряд, відновити естетичний вигляд і жувальну функцію, покращити мовлення та попередити виникнення зубоальвеолярних деформацій. Виходячи з цього, можна заявити, що протезування в даної групи осіб $є$ ще недостатньо вивченим і потребує подальшої розробки методів ортопедичного лікування.

Висновки. Перспективами подальших наукових досліджень буде аналіз і оцінка результатів проведеного ортопедичного лікування, стану зубощелепної системи. На їх основі буде аргументовано всі переваги та недоліки кожної ортопедичної конструкції. На підставі отриманих результатів дослідження запропоновано заходи ортопедичної допомоги молодому населенню з малими дефектами зубних рядів.

Інформація про конфлікт інтересів. Автори заявляють про відсутність конфлікту інтересів при виконанні наукового дослідження та підготовці даної статті.

Інформація про фінансування. Автори гарантують, що вони не отримували жодних винагород у будь-якій формі, здатних вплинути на результати роботи.

Особистий внесок кожного автора у виконання роботи:

Локота Є.Ю. - розробка концепції дослідження, проведення прийому пацієнтів, статистична обробка даних.

Оплета C.I. - аналіз літератури та отриманих результатів, написання тексту.

Локота Ю.С. - проведення прийому пацієнтів, збір матеріалів дослідження.

\section{Список використаної літератури}

1. Labunec VA, Dieva TV, Kulikov MS, Labunec OV, Lenskij VV, Rozhkova NV. Sostojanie i tendencii razvitija stomatologicheskoj ortopedicheskoj pomoshhi u lic molodogo vozrasta. Ukrainskyi stoma?olohichnyi almanakh. 2013; 5-85.

2. Ozhohan ZR, Vdovenko LP. Osoblyvosti klinichnoi kartyny defektiv zubnykh riadiv u osib molodoho viku. Dental'nye tehnologii. 2006; 3-6(28-31)-19.

3. Beliaiev EV. Osoblyvosti diahnostyky, likuvannia i reabilitatsii vtorynnykh deformatsii zuboshchelepovoi systemy. Svit medytsyny ta biolohii. 2015; 4(53)-151.

4. Vdovenko LP. Osoblyvosti vyhotovlennia i zastosuvannia naboru adhezyvnykh mostopodibnykh proteziv u khvorykh iz malymy defektamy zubnoho riadu. Ukrainskyi stomatolohichnyi almanakh. 2008; $1-14$.

5. Sydorenko LP, Ozhohan ZR. Klinichna otsinka ortopedychnoho likuvannia khvorykh iz malymy defektamy zubnykh riadiv iz zastosuvanniam naboru adhezyvnykh proteziv. 2008

6. Chernjavskij JuP, Kaveckij VP. Sovremennye podhody k ustraneniju malih defektov zubnogo rjada. Vestnik VGMU. 2011; 1.

7. Labunets OV. Kompleksna kharakterystyka stanu stomatolohichnoi ortopedychnoi zakhvoriuvanosti ta dopomohy u osib molodoho viku. Innovatsii v stomatolohii. 2014; 4-131.

8. Labunec VA, Dieva TV, Semenov EI, Diev EV, Kulikov MS, Lepsikj VV, et al. Rasprostranennost', intensivnost', struktura, tendencii razvitija malyh vkljuchennyh defektov zubnyh rjadov u lic molodogo vozrasta i ih oslozhnenij. Visnyk stomatolohii. 2013;1-93.

9. Muntian LM, Yur AM. Chastota vynyknennia, poshyrenist vtorynnykh chastkovykh adentii ta zuboshchelepnykh deformatsii u osib molodoho viku. Український Ukrainskyi stomatolohichnyi almanakh. 2010;5-25.

Стаття надійшла до редакції: 30.10.2019 р. 